\title{
Fatty Acid Composition and Cholesterol Content of Some Economic Marine Fish in Turkish Waters
}

\author{
Sebahattin KUTLU1,* (D), Gülsüm BALÇIK MISIR ${ }^{1,}$ (D), Adnan ERTEKEN² \\ ${ }^{1}$ Central Fisheries Research Institute, Vali Adil Yazar Cad. No:14, Kaşüstü, Trabzon, Turkey. \\ ${ }^{2}$ Directorate of Provincial Agriculture and Forestry, Yomra, Trabzon, Turkey.
}

\section{How to cite}

Kutlu, S., Balçık Mısır, G., Erteken, A. (2021). Fatty Acid Composition and Cholesterol Content of Some Economic Marine Fish in Turkish Waters. Aquatic Food Studies, 1(1), AFS25. https://doi.org/10.4194/AFS25

\section{Article History}

Received 23 July 2021

Accepted 30 July 2021

First Online 30 July 2021

\section{Corresponding Author \\ Tel.: +904623411053 \\ E-mail: sebakutlu@gmail.com}

\section{Keywords}

Fatty acids

Cholesterol

Commercial fish species

Black Sea

Marmara Sea

\begin{abstract}
The basic concept of balanced and healthy nutrition depends on the consumption of right foods at the right amounts. The nutrient of foods is affected by variable factors such as geographical and ecological characteristics, harvest time, processing and transportation, storage, and consumption conditions. High qualified instrumental analyses techniques should be done while the determination of the nutrient levels. Because, the quality of results of the analysis are the most important criterion in creating food composition tables, the database and data sets.

In this study, the basic nutrient composition of some economic marine fish was determined. For this, fish were collected from the Black Sea and the Marmara Sea was composites formed from the fish flesh separately for each region. Then, moisture, ash, fat, protein, fatty acids composition, and cholesterol levels were examined with the composites. While the average values were obtained according to the results of the analysis, differences among regions were examined. While the fat content in anchovy, bluefish, bonito, and barbatus is above $\% 10 \mathrm{~g} / 100 \mathrm{~g}$, in whiting was approximate \%1. Average EPA and DHA values in anchovy are \%15,86 and \%17,01 respectively. The highest cholesterol was obtained in whiting as around $77 \mathrm{mg} / 100 \mathrm{~g}$.
\end{abstract}

\section{Introduction}

As the population of the world increases rapidly, demand for seafood, including a rich amount of protein and fatty acids, increases (Christensen, Kane and Farmery 2017). Parallel to the development level of societies, increasing food content and quality comes first instead of meeting the food need (Karaca \& Kor, 2004).

As a need of the age, career activities become an act of intelligence instead of physical working. Dependent upon this, people are going towards easy digestive foods, also it is inevitable to consume foods including full of unsaturated fatty acids by getting conscious eating habits. At this point, seafood became an important source with its high protein content and high ratio of unsaturated fatty acids and essential amino acids (Bilgin et al., 2005).

Animal proteins are the main constituent of human nutrition. As it is known, animal food is the best source of essential amino acids. Seafoods, especially fish containing high quality proteins, vitamins, mineral substances and especially polyunsaturated fatty acids, is a perfect source of a balanced and adequate diet (Bilgin et al., 2004). The maintenance of healthy and adequate nutrition is to consume the right food in the right ratio. For this reason, to determine a suitable diet, especially dietitians need assays about this topic (Dönmez \& Tatar, 2001). 
The quality of fish meat especially test is affected by the fatty acid content of the fish. Fish oil is the major and unique source of EPA and DHA, these fatty acids are essential for neural development in the infant in pregnancy and during the first years of birth. Also, it has been reported that high dietary consumption of fish lipids, especially omega-3 fatty acids have preventive effects on inflammatory and auto immune disorders, coronary heart diseases depression, high cholesterol, some kinds of allergies, cancer and arrhythmias (Özyurt et al., 2007).

Besides their caloric functions, lipids contain essential fatty acids that have vital importance in human growth. In human nutrition, some fatty acids like linoleic acid, linolenic acid, and arachidonic acid are regarded as essential since they cannot be synthesized by the organism and must be taken by diet directly (Bilgin et al., 2005)

Fish lipids are composed of $20-30 \%$ saturated and $70-80 \%$ unsaturated fatty acids. The polyunsaturated fatty acids ratio is $25-30 \%$. PUFA is rich in omega- 3 and $1-3 \%$ of it is omega- 6 fatty acids (Özyurt et al., 2007).

The fat content and composition in the diet are key factors affecting serum cholesterol content and thus the risk of cardiovascular diseases. Dietary cholesterol intake as such seems to be generally of minor significance (RDA, 1989). Although, on the other hand, a lot of interest has focused on cholesterol oxidation product in various cholesterol-rich foods and the health significance of these products (Schroepfer, 2000).

The nutritional composition of foods is influenced by a number of factors such as geographic and ecological environment, processing, transfer, stocking, and consumption conditions (Löker, 2008).

Lack of data reliability is one of the important problems among the food composition tables, databases and data sets. Unfortunately, there was not any food composition database study in Turkey because of high cost (Löker et al., 2011).

Aim of this study is to systematically determine the compositions of some economical fish species (anchovy, barbatus, bonito, whiting, and bluefish) in Turkey Seas with advanced laboratory techniques and to create national documentation with provided a part of the necessary data for fish.

\section{Materials and Method}

\section{Materials}

Anchovy, barbatus, bonito, whiting and bluefish were obtained from the Black Sea and the Marmara Sea during the fishing season. Using a cold chain, fishes were sampled from 3 different regions for each sea and transported to the Trabzon Fisheries Research Institute's Food Technology Laboratory. Reached to the laboratory, fish were gutted, filleted and all fillets combined which taken from different locations. Then, Fillets were homogenized and got composites of each fish. Nutritional composition analyses were made with these composites.

\section{Methods}

Moisture

Approximately $2 \mathrm{~g}$ of wet sample was weighed into a petri dish which was brought to the constant weighing of known for 2 hours in an oven at 105으. The samples were stored in an oven at $105^{\circ} \mathrm{C}$ for 20 hours. The amount of water (\%) in the samples was determined by finding the difference between wet and dry weight and the amount of water for each sample is given (Ludorf and Meyer, 1973).

\section{Mineral Matter (Ash)}

Approximately 1 gram of the sample was weighed into brought to constant weight porcelain crucibles. After the pre-incineration process, the materials which were made into ash in $550^{\circ} \mathrm{C}$ oven for 5 hours were taken into a desiccator, cooled, and weighed. Ash amounts of the samples are given in \% (Mattissek, 1988).

\section{Amount of Mineral Matter (\%) $=[($ Last weight- First weight)/Amount of sample)] x100}

\section{Protein}

$1 \mathrm{~g}$ of homogenized fish sample was weighed into Kjeldahl tubes. After that, 1 catalyst tablet and 15-20 ml concentrated $\mathrm{H}_{2} \mathrm{SO}_{4}$ was added to this. The burning in the tubes was continued for approximately 2 hours at $420{ }^{\circ} \mathrm{C}$ until the transparent color was formed. Then, 60 $\mathrm{ml}$ of purified water and $70 \mathrm{ml}$ of $35 \% \mathrm{NaOH}$ were added to the cooling tubes and placed in the distillation unit, distilled into a graduated flask containing $25 \mathrm{ml}$ of $4 \%$ boric acid, and placed at the outlet of the distillation unit for about 5 minutes. The distillate was titrated with 0.1 $\mathrm{N} \mathrm{HCl}$. The amount of crude protein was calculated by multiplying the amount of N\% obtained by a factor of 6.25 (AOAC, 1995)

$\mathrm{N}(\%)=[(1.401 \times 0.1 \mathrm{~N} \mathrm{HCl}$ spent in titration xNormality of $\mathrm{HCl}$ used/Amount of sample) $\mathrm{x} 100$

$$
\text { Protein }(\%)=\mathrm{N}(\%) \times 6.25
$$

Lipid

Lipid analysis was performed based on the soxhlet method. Approximately $15 \mathrm{~g}$ of the sample was weighed into the extraction cartridge. The cartridge was left in the oven at 105 ㅇ $\mathrm{C}$ for 2 hours. the extraction balloons brought to constant weighing were placed under the extraction tube. Solvent (diethyl ether) was added to the extraction tube and extraction was continued for about 
2 hours. After the extraction was completed, the extraction flask was left in the oven at 105 o $C$ for 45 minutes. Lipid amount will be calculated as \% (AOAC, 1995).

$$
\begin{gathered}
\text { Lipid }(\%)=[((\text { Balloon }+ \text { Lipid })-\text { Tare of balloon }) / \\
\text { Amount of sample }] \times 100
\end{gathered}
$$

\section{Fatty acids}

Ichihara et al. (1996) method was used for fatty acid analysis. For the analysis of fatty acids methyl esters, $0.1 \mathrm{~g}$ of lipid was weighted into a $5 \mathrm{ml}$ tube with a screw cap, adding $2 \mathrm{ml}$ hexane it was dissolved, it was followed by $0.2 \mathrm{ml} 2 \mathrm{~N}$ methanolic $\mathrm{KOH}$. The clarified hexane solution was put into vials and analyzed in duplicate by the gas chromatography method.

The fatty acids composition was analyzed by GC17 A GC Shimadzu (with FID- flame ionization detector) capillary column Supelco Omega wax 320 $(30 \mathrm{~m} \times 0.32 \mathrm{~mm})$, oven temperature of column was $240^{\circ} \mathrm{C}$, Helium $(\mathrm{He})(30 \mathrm{ml} / \mathrm{min})$ was the carrier gas. The temperature of the detector was $250-260^{\circ} \mathrm{C}$, the temperature of the injection block was $250^{\circ} \mathrm{C}$. The flow rate of total gas was $50 \mathrm{ml}$, the split ratio was $1 / 25$, range 1 . Hexane was used as a solvent and it was adjusted as pour $1 \mu \mathrm{l}$ sample for each time. Supelco ${ }^{\text {TM }} 37$ Component FAME Mix (Cat. No. 47885-U) was used as standard. Three replicate GC analyses were applied and the results were represents in GC area percent as mean values \pm standard deviation.

\section{Cholesterol}

The cholesterol contents of samples were determined after direct saponification with gas chromatography (The conditions are the same as those used in fatty acid analysis) using an internal standard method. Homogenized samples $(0.5 \mathrm{~g})$ of mixed with epicholesterol as an internal standard (15 mg) were saponified with $0.5 \mathrm{~mL}$ of saturated aqueous $\mathrm{KOH}$ in $8 \mathrm{~mL}$ of absolute ethanol at $85^{\circ} \mathrm{C}$. Later dihydrocholesterol (80 mg; B95\%) was used as an internal standard. The saponification time in a gently shaking water bath was $30 \mathrm{~min}$. The unsaponifiable matter was extracted with $20 \mathrm{~mL}$ of cyclohexane from the hydrolysate diluted with $12 \mathrm{~mL}$ of water. One-sixth of the extract was dried under a gentle nitrogen stream at $50^{\circ} \mathrm{C}$. The sterols were derivatized to trimethylsilyl (TMS) ethers and analyzed with capillary gas chromatography (Toivo et al., 2001; Piironen et al., 2002).

\section{Results and Discussion}

Nutritional value, cholesterol content and fatty acids composition of fishes was shown at Table 1, Table 2 and Table 3 respectively.

Anchovy takes an important place in Turkish fisheries. According to data TUIK (2019), it has $61 \%$ of the total catch value while barbatus, bonito, whiting and bluefish $1 \%, 7 \%, 2 \%$ and $1,5 \%$ respectively. Anchovy is a pelagic fish species with high meat yield, nutritional value. It included in high fatty fish species. According to the analysis results, moisture, ash, protein, lipid and cholesterol values of the Black Sea anchovy were calculated as $67.17 \%, 1.34 \%, 17.20 \%, 12.57 \%$, and 55.4 $\mathrm{mg} / 100 \mathrm{~g}$, respectively. In the case of the Marmara anchovy, these values were $64.18 \%, 1.24 \%, 16.58 \%$, $16.15 \%$ and $55.05 \mathrm{mg} / 100 \mathrm{~g}$, respectively. Ayas (2006), found moisture, fat, protein and ash contents in anchovy as $75 \%, 3 \%, 20 \%, 1.3 \%$ respectively. Inanlı et al. (2010) also calculated moisture, protein and lipid values for anchovy as $70 \%, 16.61 \%, 7.1 \%$ respectively.

There is a cross relationship between lipid and moisture contents of fisheries products. In this study, moisture and lipid ratios were found as $61.75 \%$ and 20.05\% for the Black Sea bluefish.

Lipid content in fish is widened in a scale of 0.3$45 \%$. Fish are classified according to lipid contents; non fat $(<1 \%)$, low fatty $(1-5 \%)$, semi fatty $(5-10 \%)$, and fatty $(>10 \%)$ (Rehbein, 1996). According to these data anchovy, barbatus, bonito, and bluefish are fatty fish species and whiting is low fatty species.

Lipid and fatty acid composition of seafood differ according to some factors such as feeding habits, geographic conditions, environmental temperature, catching according to the seasons, body length, sex, and species (Bilgin et al., 2004). Tablo 1 is a good example to show this situation. Lipid contents of bluefish obtained from the Marmara Sea and the Black Sea were 14.36\% and $20.05 \%$, respectively. Similarly, lipid content in anchovy from the Black Sea was $12.57 \%$ when this ratio differs as $16.15 \%$ for anchovy from the Marmara Sea.

Ozogul et al. (2007) determined the lipid contents and fatty acid compositions of 8 fish species. According to their results, the lipid content of whiting was found as $1.20 \%$. Similarly, in present study, whiting fat ratio was $1.06 \%$ in the Marmara Sea.

Nutritional composition values of our study were parallel to values of food databases of the USA. According to the USA database cholesterol value of anchovy is 60-90, when the same fish value obtained from the Marmara Sea and the Black Sea in our study was $55.05 \mathrm{mg} / 100 \mathrm{~g}$ and $57.40 \mathrm{mg} / 100 \mathrm{~g}$ respectively. Piironen et al., (2002) studied cholesterol contents in meat, fish and milk consumed in Finland. In their research, a noteworthy result was that the cholesterol contents did not correlate with the fat content; the highest cholesterol content, $92 \mathrm{mg} / 100 \mathrm{~g}$, was measured in perch with $1.4 \%$ fat whereas rainbow trout with $12.6-14.3 \%$ fat contained $58.6-65.0 \mathrm{mg} / 100 \mathrm{~g}$ of cholesterol. Similarly, in present study cholesterol value of whiting is $79 \mathrm{mg} / 100 \mathrm{~g}$ with $0.88 \%$ fat content whereas bonito has $58.10 \mathrm{mg} / 100 \mathrm{~g}$ cholesterol content with $14.43 \%$ fat value. Nutritional values also show similarities for the fish species in Denmark food database and determined this study. Protein, lipid and ash contents of whiting is $18.2 \%, 0.6 \%, 1.2 \%$ respectively 
Table 1. Biochemical composition of some economical fish belong to Turkey

\begin{tabular}{|c|c|c|c|c|c|c|}
\hline & & Ancohvy & Barbatus & Bonito & Whiting & Bluefish \\
\hline \multirow{5}{*}{ 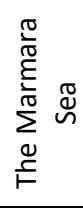 } & Moisture \% & $64.18 \pm 0.55$ & $68.00 \pm 0.42$ & $63.72 \pm 0.16$ & $82.75 \pm 0.01$ & $66.50 \pm 0.28$ \\
\hline & Protein \% & $16.58 \pm 0.65$ & $18.03 \pm 0.12$ & $19.61 \pm 0.37$ & $15.46 \pm 0.57$ & $17.95 \pm 0.22$ \\
\hline & Ash \% & $1.24 \pm 0.13$ & $1.44 \pm 0.03$ & $1.09 \pm 0.05$ & $1.26 \pm 0.13$ & $0.99 \pm 0.15$ \\
\hline & Fat $\%$ & $16.15 \pm 0.46$ & $11.91 \pm 0.09$ & $14.67 \pm 0.57$ & $1.06 \pm 0.25$ & $14.36 \pm 0.75$ \\
\hline & Cholesterol mg/100 g & $55.05 \pm 0.75$ & $65.37 \pm 0.52$ & $44.32 \pm 0.26$ & $75 \pm 1.2$ & $53.74 \pm 0.81$ \\
\hline \multirow{5}{*}{ 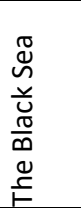 } & Moisture \% & $67.17 \pm 0.47$ & $67.12 \pm 0.17$ & $62.45 \pm 0.81$ & $83.00 \pm 0.30$ & $61.75 \pm 0.62$ \\
\hline & Protein \% & $17.20 \pm 0.32$ & $16.36 \pm 0.21$ & $20.30 \pm 0.19$ & $15.07 \pm 0.25$ & $16.79 \pm 0.26$ \\
\hline & Ash \% & $1.34 \pm 0.03$ & $1.56 \pm 0.12$ & $1.10 \pm 0.16$ & $1.29 \pm 0.31$ & $0.91 \pm 0.20$ \\
\hline & Fat $\%$ & $12.57 \pm 0.84$ & $13.77 \pm 0.33$ & $14.43 \pm 0.55$ & $0.88 \pm 0.70$ & $20.05 \pm 0.32$ \\
\hline & Cholesterol mg/100 g & $57.40 \pm 0.23$ & $70.23 \pm 0.46$ & $59.10 \pm 0.87$ & $79 \pm 0.95$ & $52.01 \pm 0.26$ \\
\hline
\end{tabular}

Table 2. Fatty acid composition of some of the Marmara Sea fishes

\begin{tabular}{lccccc}
\hline \multirow{2}{*}{ Fatty acid } & \multicolumn{5}{c}{ The Marmara Sea } \\
\cline { 2 - 6 } & Anchovy & Barbatus & Bonito & Whiting & Bluefish \\
\hline C14:0 & $5.89 \pm 0.01$ & $2.26 \pm 0.08$ & $4.65 \pm 0.01$ & $3.64 \pm 0.12$ & $5.07 \pm 0.01$ \\
C16:0 & $16.35 \pm 0.02$ & $23.56 \pm 0.01$ & $19.56 \pm 0.15$ & $18.41 \pm 0.09$ & $21.33 \pm 0.33$ \\
C18:0 & $2.69 \pm 0.01$ & $5.29 \pm 0.34$ & $4.14 \pm 0.01$ & $7.28 \pm 0.25$ & $5.77 \pm 0.24$ \\
C20:0 & $1.66 \pm 0.01$ & $1.18 \pm 0.12$ & $2.09 \pm 0.24$ & $0.51 \pm 0.15$ & $1.91 \pm 0.01$ \\
$\sum$ SFA & $26.59 \pm 0.25$ & $32.29 \pm 0.28$ & $30.44 \pm 0.63$ & $29.84 \pm 0.06$ & $34.08 \pm 0.48$ \\
\hline C16:1 n-7 & $9.70 \pm 0.11$ & $8.4 \pm 0.01$ & $6.67 \pm 0.45$ & $4.54 \pm 0.08$ & $6.09 \pm 0.04$ \\
C18:1 n-9 & $15.90 \pm 0.01$ & $27.73 \pm 0.12$ & $20.39 \pm 0.32$ & $16.56 \pm 0.51$ & $22.32 \pm 0.03$ \\
C20:1 & $1.75 \pm 0.01$ & $0.29 \pm 0.07$ & $1.65 \pm 0.01$ & $1.37 \pm 0.14$ & $0.78 \pm 0.07$ \\
$\sum$ MUFA & $27.35 \pm 0.25$ & $36.42 \pm 0.13$ & $28.71 \pm 0.17$ & $22.47 \pm 0.09$ & $29.19 \pm 0.25$ \\
\hline C18:2 n-6 & $0.16 \pm 0.02$ & $0.40 \pm 0.01$ & $0.15 \pm 0.01$ & $1.59 \pm 0.10$ & $0.18 \pm 0.11$ \\
C18:3 n-3 & $1.13 \pm 0.01$ & $1.62 \pm 0.07$ & $1.55 \pm 0.01$ & $1.98 \pm 0.02$ & $1.13 \pm 0.01$ \\
C20:4 n-6 & $0.83 \pm 0.03$ & $1.29 \pm 0.15$ & $0.79 \pm 0.06$ & $1.53 \pm 0.03$ & $0.96 \pm 0.08$ \\
C20:5 n-3 & $15.83 \pm 0.20$ & $5.93 \pm 0.33$ & $7.68 \pm 0.03$ & $5.93 \pm 0.33$ & $5.91 \pm 0.09$ \\
C22:6 n-3 & $16.32 \pm 0.04$ & $3.90 \pm 0.04$ & $17.23 \pm 0.22$ & $15.46 \pm 0.27$ & $15.08 \pm 0.56$ \\
$\sum$ PUFA & $34.27 \pm 0.22$ & $13.14 \pm 0.05$ & $27.4 \pm 0.26$ & $26.49 \pm 0.11$ & $23.26 \pm 0.08$ \\
\hline
\end{tabular}

Table 3. Fatty acid composition of some of the Black Sea fishes.

\begin{tabular}{lccccc}
\hline \multirow{2}{*}{ Fatty acid } & \multicolumn{5}{c}{ The Black Sea } \\
\cline { 2 - 5 } & Anchovy & Barbatus & Bonito & Whiting & Bluefish \\
\hline C14:0 & $6.02 \pm 0.01$ & $2.18 \pm 0.85$ & $4.84 \pm 0.05$ & $3.21 \pm 0.01$ & $4.28 \pm 0.01$ \\
C16:0 & $17.42 \pm 0.02$ & $23.01 \pm 0.21$ & $19.61 \pm 0.01$ & $16.56 \pm 0.14$ & $22.55 \pm 0.01$ \\
C18:0 & $3.66 \pm 0.11$ & $4.50 \pm 0.04$ & $4.39 \pm 0.03$ & $6.18 \pm 0.06$ & $6.55 \pm 0.02$ \\
C20:0 & $2.03 \pm 0.01$ & $0.48 \pm 0.01$ & $2.35 \pm 0.01$ & $0.37 \pm 0.01$ & $1.85 \pm 0.05$ \\
$\sum$ SFA & $29.13 \pm 0.09$ & $30.17 \pm 0.02$ & $31.19 \pm 0.32$ & $26.32 \pm 0.45$ & $35.23 \pm 0.03$ \\
\hline C16:1 n-7 & $7.08 \pm 0.25$ & $9.17 \pm 0.03$ & $6.01 \pm 0.06$ & $4.36 \pm 0.04$ & $6.19 \pm 0.07$ \\
C18:1 n-9 & $14.25 \pm 0.04$ & $28.73 \pm 0.01$ & $18.24 \pm 0.01$ & $14.34 \pm 0.18$ & $24.95 \pm 0.09$ \\
C20:1 & $1.41 \pm 0.03$ & $0.17 \pm 0.02$ & $1.63 \pm 0.04$ & $0.53 \pm 0.01$ & $0.86 \pm 0.01$ \\
$\sum$ MUFA & $22.74 \pm 0.52$ & $38.07 \pm 0.05$ & $25.88 \pm 0.01$ & $19.23 \pm 0.45$ & $32.00 \pm 0.01$ \\
\hline C18:2 n-6 & $0.14 \pm 0.02$ & $0.58 \pm 0.04$ & $0.20 \pm 0.01$ & $1.59 \pm 0.02$ & $0.12 \pm 0.03$ \\
C18:3 n-3 & $1.13 \pm 0.01$ & $1.96 \pm 0.01$ & $2.52 \pm 0.07$ & $2.26 \pm 0.05$ & $1.58 \pm 0.01$ \\
C20:4 n-6 & $0.97 \pm 0.01$ & $1.20 \pm 0.01$ & $0.73 \pm 0.01$ & $0.82 \pm 0.10$ & $0.93 \pm 0.01$ \\
C20:5 n-3 & $12.69 \pm 0.05$ & $4.60 \pm 0.01$ & $7.39 \pm 0.30$ & $5.05 \pm 0.22$ & $5.30 \pm 0.02$ \\
C22:6n-3 & $17.70 \pm 0.01$ & $3.65 \pm 0.13$ & $17.82 \pm 0.05$ & $15.37 \pm 0.17$ & $14.21 \pm 0.04$ \\
$\sum$ PUFA & $33.63 \pm 0.12$ & $11.99 \pm 0.06$ & $28.66 \pm 0.01$ & $25.09 \pm 0.15$ & $22.14 \pm 0.03$ \\
\hline
\end{tabular}


in Denmark database while $15.46 \%, 0.88 \%$ and $1.26 \%$ respectively in this study.

Table 2 shows the fatty acids composition of anchovy, barbatus, bonito, whiting and bluefish inhabiting in the Marmara Sea. ¿SFA was the highest in bluefish and lowest in anchovy as $34.08 \%$ and 26.59 respectively. Major fatty acids were palmitic acid, oleic acid, EPA and DHA. EPA and DHA were the most abundant PUFA in most of the fish species.

The maximum $\Sigma$ MUFA belongs to barbatus and the minimum whiting. In the case of $\angle P U F A$, the highest value was found in anchovy and the lowest in barbatus. Among fish species anchovy has a good amount of EPA and DHA. Minimum DHA and EPA contents belongs to barbatus.

Table 3 represents the fatty acids compositions of anchovy, barbatus bonito, whiting and bluefish from the Black Sea. Similar to the Marmara Sea species, bluefish has the highest $\Sigma$ SFA ratio but the minimum $\Sigma$ SFA ratio belongs to whiting. Also LMUFA ratios of the Black Sea species were similar highest value belongs to barbatus and the lowest value belongs to whiting. The maximum ¿PUFA content was found in anchovy. Similar EPA and DHA contents were belong to anchovy and bonito.

Oleic acid was the major MUFA. It was the highest in barbatus with the ratio of $28.73 \%$. Oleic acid was followed by palmitic acid in all species and two seas.

HSMO (1994) advised maximum n6/n3 ratio as 4.00 , and added that higher than this ratio may cause health problems. The same organization recommended a minimum PUFA/SFA ratio as 0.45 . In present study $\mathrm{n} 6 / \mathrm{n} 3$ ratios changing from 0.03 to 0.17 in anchovy of the Marmara Sea and the Black Sea, respectively.

\section{Conclusions}

The chemical composition of foods represents an important link between human health and nutrition. Improving the quality of public life, forming national nutrition policies, determining the nutrition, and health status of the population and providing adequate nutrition for people are major necessities for countries. Therefore, high quality instrumental analysis techniques should be applied during the determination of nutrient levels. Because the quality of the analysis results is the most important criterion in the creation of food composition tables, data sets and databases. This study was funded by TÜBITAK, contributed provide data for the Turkish Food Database.

\section{Ethical Statement}

Ethical approval was not required for this study.

\section{Funding Information}

This study was funded by TÜBITAK, KAMAG TARAL 1007 Program with no: $107 \mathrm{G} 208$ project.

\section{Author Contribution}

SK: Conceptualization, methodology, writing, review and editing; GBM: Writing, analysis, editing; AE: Analysis.

\section{Conflict of Interest}

There was no conflict of interest in the preparation of this article.

\section{References}

Christensen JK, Kane GM, Farmery AK., 2017, The barriers and driversof seafood consumption in Australia: a narrative literature review. Intl J Cons Stud. 41:299-311

AOAC, 1995, Official Method 960.52, Microchemical Determination of Nitrogen-Micro Kjeldahl Mehod

Ayas, D., 2006, Gökkuşağı Alabalığı (Oncorhynchus mykiss), Hamsi (Engraulis Encrasicolus) ve Sardalya (Sarda Pilchardus)'nın Sıcak Tütsülenmesi Sonrasındaki Kimyasal Kompozisyon Oranlarındaki Değişimleri, E.Ü. Su Ür. Der., 23(1-3), 343-34

Bilgin, Ş., Ünlüsayın, M., Günlü, A. ve İzci, L., 2005, Sudak (Sander lucioperca Bogustkaya ve Naseka, 1996) ve Kadife (Tinca tinca L.,1758) Balığından Balık ezmesi (PATE) Yapımı, Bazı Kimyasal Bileşenlerin ve Kalite Kriterlerinin Belirlenmesi, E.Ü. Su Ür. Der., 22(3-4), 399402

Bilgin, S., Samsun, N., Kalaycı, F. ve Samsun, O., 2004, Zargana Balığı (Belone belone euxini Günther, 1866) Et veriminin mevsim, yaş ve cinsiyete gore değişimi, S.D.Ü., Eğirdir Su Ürün. Fak. Der., c:2, s: 12, 1-6

Dönmez, M. ve Tatar, O., 2001, Fileto ve Bütün Olarak Dondurulmuş Gökkuşağı Alabalığının (Oncorhynchus mykiss W.) Muhafazası Süresince Yağ Asitleri Bileşimlerindeki Değişmelerin Araştırılması, E.Ü. Su Ür. Der., 18(1-2), 125-134

Fenton, M and Sim, J.S, 1991, Determination of egg yolk cholesterol content by on-column capillary gas chromatography, Journal of Chromatography, 540, 323329

Ichihara, K., Shibahara, A., Yamamoto, K. and Nakayama, T., 1996, An Improved Method for Rapid Analysis of the Fatty Acids of Glycerolipids, Lipids, 31, 535-539

İnanlı, A.G., Özpolat, E., Çoban, Ö., Karaton, N., 2010, Marine Edilmiş Hamsi Balığının (Engraulis Encrasicolus L., 1758) Kimyasal Bileşimi ve Farklı Soslarda Duyusal Değerlendirilmesi, J. of Fisheries Scie., 4(4), 455-461

HMSO UK., 1994, Nutritional aspects of cardiovascular disease (report on health and social subjects No. 46). London: HMSO.

Karaca, S. ve Kor, A., 2004, Ruminant Karkaslarında Yağ Asidi Kompozisyonuna Etkili Faktörler, Yüzüncü Yıl Üniversitesi, Ziraat Fak., Zootekni Böl. Ders Notlar

Löker, G.B., 2008, Ulusal Gıda Kompozisyonunun Belirlenmesi ve Yaygın-Sürekli Paylaşım Sisteminin Oluşturulması, 107G282, TÜBITAK 1007 Projesi

Löker, G.B., Özkoç, Amoutzopoulos, B, Yaman, M, Akkuş, S., 2011, Turkish Food Composition Database Constructed Within a Traceable Approach, Nütition Bülletin, in press

Ludorf, F.W. ve Meyer, V., 1973, Fisch und Fischerzeugnisse, Paul Parey Verlag, 95-11 
Mattissek, R., Shengel, F. M. and Steiner, G. (1988) Lebensmittel-Analytick. Springer Verlag Berlin, Tokyo, 440p.

Özyurt, G.,Tokur, B. Özoğul,Y., 2007, İncedudaklı Kefal (Liza ramada)'in Yağ Asidi Kompozisyonu ve Buzdolabında Muhafazası $\left(4^{\circ} \mathrm{C}\right)$ Sırasında Lipit Oksidasyonu, Journal of Fisheries Sci., 1(4), 160-167

Özogul, Y. \& Özogul, F. (2007). Fatty acid profiles of commercially important fish species from the Mediterranean, Aegean and Black Seas. Food Chemistry, 100, 1634-1638.

Piironen, V., Toivo, J., Lampi, AM.M., 2002, New Data for Cholesterol Contents in Meat, Fish, Milk, Egg and Their Products Consumed in Finland Journal of Food Composition and Analysis, 15: 705-713

Piironen, V., Toivo, J., and Lampi, A.-M., 2002, Plant sterols in cereals and cereal products. Cereal Chem. 79, 148-154.
Rehbein, H., Oehlennschlager, 1996, Fische und Fischerzeug nisse, Krebs und Weichtiere, Behr's Verlag, 395-396

RDA., 1989, Recommended Dietary Allowances. 10thedn. National Academy Press, Washington, DC.

Schroepfer, G. J., Jr., 2000, Oxysterols: modulators of cholesterol metabolism and other processes. Physiol. Rev. 80, 361-554.

Şengör, G.F., Çelik, U. ve Akkuş, S., 2000, Buzdolabı Koşullarında Depolanan İstavrit Balığı (Trachurus trachurus, L.1758)'nın Tazeliğinin ve Kimyasal Bileşiminin Belirlenmesi, Turk J. Vet. Anim. Sci., 24, 187-193

Toivo, J., Phillips, K., Lampi, A.-M., and Piironen, V. (2001). Determination of sterols in foods: Recovery of free, esterified, and glycosidic sterols. J. Food Comp. Anal. 14, 631-643.

TÜIK, 2020, Su Ürünleri İstatistikleri 